\title{
Intraventricular infusion of clusterin ameliorated cognition and pathology in Tg6799 model of Alzheimer's disease
}

\author{
Xue-Mei Qi, Cheng Wang, Xing-Kun Chu, Gen Li and Jian-Fang Ma* (D)
}

\begin{abstract}
Background: Alzheimer's disease (AD) is characterized by the deposition of amyloid- $\beta$ (A $\beta$ ) in brain parenchyma and cerebral blood vessels as cerebral amyloid angiopathy (CAA). Clusterin, a chaperon protein associated with A $\beta$ aggregation, toxicity and transport through blood-brain barrier, may play a key role in the development of AD. Recently, clusterin peptide D-[113-122] was shown to mimic clusterin's function and exerted therapeutic effect in atherosclerosis. In this study, we investigated whether this clusterin peptide also affected $(A \beta)$ deposition in AD transgenic mouse.

Results: Using a micropump, synthetic peptide 113-122 of clusterin protein $(20 \mu \mathrm{g} / 200 \mu \mathrm{l})$ was infused into the lateral ventricle of 8-month $5 \times$ FAD transgenic mouse model (Tg6799), for 2 weeks. Water-maze testing showed an improved cognitive function of the Tg6799 mice treated with clusterin. Immunocytochemistry and quantitative analysis revealed that intraventricular (icv) administration of clusterin peptide in Tg6799 mouse reduced A $\beta$ plaques as well the severity of cerebral amyloid angiopathy. Enzyme-linked immunosorbent assay demonstrated a decreased in the soluble levels of $A \beta(A \beta 40$ and $A \beta 42$ ) in the brain. Western-blot revealed an increased level of LRP- 2 after clusterin peptide treatment.
\end{abstract}

Conclusion: These results suggest that icv infusion of clusterin peptide D-[113-122] offers a promising therapeutic approach to reduce A $\beta$ deposition as well as CAA. The LRP2-mediated clearance system might be involved in the mechanism of these effects.

Keywords: Clusterin, Alzheimer's disease, LRP-2, Amyloid

\section{Background}

Alzheimer's disease (AD) is a common neurodegenerative disease in elderly. Pathologically, it is characterized by abnormal amyloid deposition such as amyloid plaque and cerebral amyloid angiopathy (CAA), neurofibrillary tangle and neuron loss. Amyloid-beta $(\mathrm{A} \beta)$ is considered to play a key role in AD pathological processes [1]. Vascular clearance of $A \beta$ was one of mechanisms contributing to the pathogenesis of $\mathrm{AD}[2-4]$ and new therapeutic method targeting on neurovascular system has made a crucial development for AD treatment $[5,6]$.

\footnotetext{
*Correspondence: majifa@hotmail.com

Department of Neurology and Institute of Neurology, Ruijin Hospital Affiliated to Shanghai Jiao Tong University School of Medicine, No. 197, Road Ruijin Second, Shanghai 200025, People's Republic of China
}

Clusterin, also named apolipoprotein J, is a major glycoprotein firstly identified in ram rete testis fluid [7] and recently shown to play an important role in $\mathrm{AD}$ [8]. Genetic polymorphisms of clusterin were found to be associated with risk of $\mathrm{AD}$ in different populations [9-14]. Vitro studies demonstrated that clusterin could bind amyloid $\beta(A \beta)$ to prohibit aggregation by its molten globule domains [15]. In addition, clusterin was shown to bind low density lipoprotein receptor-2 (LRP-2) to facilitate $A \beta$ clearance $[16,17]$. This pathway could cooperate with Apolipoprotein E, another well-known risk factor of $\mathrm{AD}$ to maintain vascular clearance of $\mathrm{A} \beta[18,19]$.

Interestingly, a clusterin peptide synthesized from D-amino acids corresponding to residues 113-122 was found to mimic the function of clusterin. Navab et al. [20] reported that clusterin peptide D-[113-122] inhibited 
high-density lipoprotein (LDL)-induced monocyte chemotactic activity and improved HDL inflammatory properties in apoE-null mouse. However, it remained unknown whether this peptide could also mimic the function of clusterin on $A \beta$ metabolism. In addition, Takker et al. [21] found that intraventricular (icv) delivery of $A \beta$ antibody was superior to systemic infusion for modulating $\mathrm{A} \beta$ deposition, especially for CAA. So in this study, we investigated whether intraventricular administrating clusterin peptide D-[113-122] could reduce amyloid deposition and hence improve memory impairment in an $\mathrm{AD}$ transgenic mouse.

\section{Methods}

\section{Animals}

All experiments were performed using female $5 \times$ FAD mice (Tg6799 mice) at 8 months which harbor mutations in amyloid precursor protein (APP) and presenilins (PS1) and cause familial Alzheimer's disease (FAD) [22]. In Tg6799 mice, significant amyloid deposition developed at 6-9 months and impaired memory at 4-5 months. For all experiment, mice were divided into three groups: no treatment $(n=10)$, saline treatment $(n=10)$ and clusterin peptide D-[113-122] treatment group $(n=10)$. All mice were performed according to the National Institutes of Health Guide for the Care and Use of Laboratory Animals with the approval (permit number: SYXK-2011-0113) of the Scientific Investigation Board of Shanghai Jiao Tong University School of Medicine, Shanghai, China. Protocols were performed with the approval of the Institutional Animal Care and Use Committee (IACUC) at Shanghai Jiao Tong University, Shanghai, China.

\section{Clusterin peptide D-[113-122] preparation}

Clusterin protein D-[113-122] peptides were corresponding to LVGRQLEEFL residue of amino acid and synthesized by Sangon Blotech (Shanghai). Clusterin peptide D-[113-122] powder was dissolved in 1\% DMSO solution and diluted in saline to a final concentration of $20 \mu \mathrm{g} / 200 \mu \mathrm{l} .200 \mu \mathrm{l}$ clusterin peptide was infused into lateral ventricle of 8-months-old $\operatorname{Tg} 6799$ transgenic mouse by using micro pump for 2 weeks.

\section{Stereotactic administration}

Mice aged 8 months were anesthetized with 5\% chloral hydrate and then mounted in a stereotactic apparatus (David Kopf instrument) for intracerebroventricular injections. Injections of Clusterin polypeptide D-[113122] $(20 \mu \mathrm{g} / 200 \mu \mathrm{l})$ or saline were conducted using ALZET Brain Infusion Kit 3 and ALZET Mini-osmotic Pump Model 2002 (200 $\mu$ l, number: 0008851). Briefly after making a middle skin incision in the cranial skin, the pump filled with solution was placed into a formed subcutaneous pocket on the back of the mouse. The brain infusion cannula of the Brain Infusion Kit was implanted into the lateral ventricle. Coordinates of the injection sites relative to bregma were anteroposterior (AP): $-0.1 \mathrm{~mm}$, lateral (L): $+0.9 \mathrm{~mm}$, dorsoventral (DV): $-2.5 \mathrm{~mm}$. After sufficient awakening from anesthesia, animals were returned to their cages for 14 days. Then a small incision was made in the skin of mouse after anesthetized and the pump reservoir was removed. The brain infusion cannula was left in place. After surgery the animal was returned to the cage for 4 days. Then the mouse underwent cognitive testing.

\section{Morris water maze test}

The Morris water maze is a classic behavioral test to evaluate spatial learning and memory function [23]. It is an open circular pool with $120 \mathrm{~cm}$ in diameter that is filled with $20^{\circ} \mathrm{C}$ opaque water (dyed white with food colorants) located in a room with extra-maze cues. A highresolution camera was suspended over the center of the pool and its images were monitored by a video-tracking system (Morris Water Maze Video Analysis System (DigBeh-MM), Shanghai Jiliang Software Technology Co. Ltd, Shanghai, China). The pool was divided into four equal quadrants: Northeast (NE), Southeast (SE), northwest $(\mathrm{NW})$ and Southwest (SW). A platform $(9 \mathrm{~cm}$ in diameter) is located in the middle of the NE quadrant. The Morris water maze test included 1-day of training making the mice familiarized to the device, 4 consecutive days of acquisition training with a hidden platform $(1 \mathrm{~cm}$ below the water, the platform was remained in a fixed location for the entire test), and 1 day of probe trial. On the first day animals were familiarized to the device. For the following acquisition training, animals were given a series of training at a rate of 4 trails per day for 4 consecutive days with the platform hidden below the water. For each trial the mouse must find a hidden platform located in the NE quadrant within $60 \mathrm{~s}$ and was left on it for an additional $20 \mathrm{~s}$. Mice not finding the platform within $60 \mathrm{~s}$ were placed on it or guided to it gently and left on the platform for $20 \mathrm{~s}$. Each mouse received four training trials per day with an average inter-trial interval of $15 \mathrm{~min}$. The daily order of entry into individual quadrants was randomized. The escape latency and distance to reach the platform were recorded by the video-tracking system. On the following day, the platform was removed and a $60 \mathrm{~s}$ probe trial was conducted. The spatial memory was evaluated by comparing the time spent in the NE quadrant to the time spent in the 3 other quadrants. 


\section{Immunohistochemistry}

One day after the end of behavioral tests, Mice were anesthetized and perfused with phosphate-buffered saline (PBS) by cardiac perfusion. The brains were immediately removed and bisected. One hemisphere was frozen in $-80{ }^{\circ} \mathrm{C}$ for further protein analysis. The other hemisphere was fixed in $4 \%$ paraformaldehyde for $24 \mathrm{~h}$ followed by gradient dehydration in 15, 20 and $30 \%$ sucrose and then embedded in optimum cutting temperature embedding compound (OCT) (Miles Diagnostics, Elkhart, IN, USA) in a coronal orientation. OCT-embedded tissues were cut at $13 \mu \mathrm{m}$ thickness. The brain sections were blocked with $10 \%$ goat serum, and then incubated overnight with polyclonal A $\beta 42$ antibody (SIGMA, Anti-Amyloid Peptide $\beta$, Cleavage Site 42 antibody produced in rabbit, 1:1000) or $A \beta 40$ antibody (Cell Signaling Technology, $\beta$-Amyloid (1-40 Specific) (D8Q7I) Rabbit mAb, 12990S, 1:800) at $4{ }^{\circ} \mathrm{C}$ overnight. PBS was used in place of primary antibody as a negative control. After incubation with secondary antibody (Jackson Immuno Research, Peroxidase AffiniPure Goat Anti-Rabbit IgG (H + L) 111-035-003, 1:1000), immunoreactivity was detected with DAB, and sections were counterstained with hematoxylin. Images of three sections through both anatomic regions of interest (entorhinal cortex and region of the hippocampus) were captured from each animal, and a threshold optical density was obtained that discriminated staining from background. The percent area occupied by the plaques was determined stereologically in the hippocampus section immunostained with A $\beta 42$ antibody. CAA burden, expressed as percent area occupied by vessels with CAA (immunostained with A $\beta 40$ antibody) in temporal cortex.

\section{Enzyme-linked immunosorbent assay}

Homogenates of hippocampus and the surrounding temporal tissue were prepared. Measurement of soluble $A \beta$ peptides were quantified by specific ELISA kits (human Amyloid beta 40 ELISA Kit, ExCell Bio EH039; human Amyloid beta 42 ELISA Kit, ExCell Bio EH040). Assays were performed on 96-well plates according to the manufacturer's recommendations and reproducibility of the assay for $A \beta 40$ and $A \beta 42$ were: Inter-Assay $\mathrm{CV}<10 \%$, Intra-Assay $\mathrm{CV}<10 \%$. Briefly, the sample was added into precoated plate and following incubated for $4{ }^{\circ} \mathrm{C}$ overnight, each well of precoated plate was washed with washing buffer. Then the biotin-conjugated antibody solution was added into the well and incubated for $120 \mathrm{~min}$ at $37^{\circ} \mathrm{C}$. After washing, streptavidin-HRP was added and then incubated for $60 \mathrm{~min}$ at $37{ }^{\circ} \mathrm{CR}$. After washing, substrate solution was added and then incubated for 10-15 $\mathrm{min}$ at room temperature in the dark.
Following adding stop solution, the resulting was assayed at $450 \mathrm{~nm}$ using Bio Tek Synergy 4.

\section{Western blot analysis}

The temporal cortex and hippocampus of the brain were dissected and tissues were analyzed by Western blot as previously described [24]. Homogenates of brain tissue (hippocampus, and the surrounding temporal cortex) were prepared in RIPA buffer $(50 \mathrm{mmol} / \mathrm{l}$ Tris $\mathrm{HCl}(\mathrm{pH}$ 8.0), $150 \mathrm{mmol} / \mathrm{l} \mathrm{NaCl}, 1 \% \mathrm{NP}-40,0.5 \%$ sodium deoxycholate, and $0.1 \%$ sodium dodecyl sulfate [SDS]) with protease inhibitor cocktail and PMSF (Beyotime). After 30 min incubation on ice, the homogenates were then centrifuged at $12,000 \mathrm{~g}$ for $15 \mathrm{~min}$ at $4{ }^{\circ} \mathrm{C}$, then the supernatants were collected and protein concentration was determined by the BCA assay (Thermo). Equal amounts of protein from the supernatant were separated using $7.5 \%$ sodium dodecyl sulfate gel, and proteins were transferred to a nitrocellulose membrane after electrophoresis. The LRP2 protein was probed with primary antibody (Anti-Lrp2/Megalin antibody [EPR5875] ab129198, 1:5000) at $4{ }^{\circ} \mathrm{C}$ overnight. After three washes with TBST, the membrane was incubated in horseradish peroxidase-conjugated secondary antibody (Jackson Immuno Research, Peroxidase AffiniPure Goat Anti-Rabbit IgG $(\mathrm{H}+\mathrm{L})$ 111-035-003, 1:10,000) for $1 \mathrm{~h}$ at room temperature. A monoclonal mouse antibody against $\beta$-actin was used to control protein loading and transfer efficiency. Membranes were incubated in Immobilon Western Chemiluminescent HRP Subtrate reagent (Millipore) and exposed to X-ray film (Kodak, Rochester, NY/USA) and analyzed using the NIH Image J software.

\section{Statistical analyses}

Data are present as mean \pm SEM. Multiple comparisons were evaluated by two-tailed ANOVA and Turkey test for comparison between two groups with SPSS 19.0 and $p$ value $<0.05$ was considered statistically significant. All experiments were performed three times.

\section{Results Icv-delivering clusterin peptide D-[113-122] improved memory dysfunction of Tg6799 transgenic mouse}

We firstly investigated whether clusterin peptide D-[113122] infusion could improve the memory dysfunction of Tg6799 transgenic mouse by Morris water maze test. After intraventricular infusion of clusterin peptide for 2 weeks, we found that there was a significant difference of acquisition trial swimming time among three groups $(\mathrm{F}(2,27)=4.54, \mathrm{p}=0.020$ on day $3 ; \mathrm{F}(2,27)=5.57$, $\mathrm{p}=0.009$ on day 4$)$. The post Turkey test for comparison between two groups showed that the acquisition trial swimming time were significant decreased in clusterin 
group in comparison to non-treat group ( $\mathrm{p}=0.040$ on day 3; $p=0.027$ on day 4$)$ and saline group $(p=0.035$ on day 3; $\mathrm{p}=0.015$ on day 4) (Fig. 1a, c). The clusterin group also showed improvement of performance in swimming distance in 4 consecutive training trials (Fig. 1c). In the probe test the time spent in the goal quadrant was different among three groups $(F(2,27)=5.83, p=0.008)$, and the following Turkey test showed that clusterin treated group showed more time spent in the goal quadrant (Fig. 1b) as opposed to non-treat $(\mathrm{p}=0.020)$ and NS mice $(p=0.015)$. These results suggested that clusterin peptide D-[113-122] was able to improve memory impairment in $\mathrm{AD}$ transgenic mouse.

\section{Clusterin peptide $D-[113-122]$ reduced $A \beta$ deposition in Tg6799 transgenic mouse}

We secondly examined whether $A \beta$ deposition decreased in Tg6799 transgenic mouse after icv-administration of clusterin peptide D-[113-122]. In hippocampus slice, histoimmunochemistry by $\mathrm{A} \beta 42$ antibody showed that amyloid plaque load was different among three groups $(\mathrm{F}(2,12)=15.14, \mathrm{p}=0.001)$, and the following Turkey test for comparison between two groups indicated that amyloid plaque was reduced in clusterin group (Fig. 2C, F) than non-treat group $(\mathrm{p}=0.01)$ (Fig. 2A, D) and saline group ( $p=0.04)$ (Fig. $2 \mathrm{~B}, \mathrm{E})$. In temporal lobe cortical slice, histoimmunochemistry by $A \beta 40$ antibody showed that there was a significant difference of CAA among three groups $(\mathrm{F}(2,12)=27.79, \mathrm{p}<0.001)$ and the post Turkey test showed that CAA was reduced in clusterin group (Fig. 2I) than non-treat group ( $<$ 0.001) (Fig. 2G) and saline group $(\mathrm{p}=0.001)$ (Fig. $2 \mathrm{H})$. These results suggested that the improvement of memory impairment after clusterin peptide $\mathrm{D}$-[113-122] treatment might be mediated by reducing $\mathrm{A} \beta$ deposition in $\mathrm{AD}$ transgenic mice.

\section{Clusterin peptide $D-[113-122]$ decreased soluble $A \beta$ level in Tg6799 transgenic mouse}

In order to examine the possible mechanism of this therapeutic effect of clusterin peptide in reducing

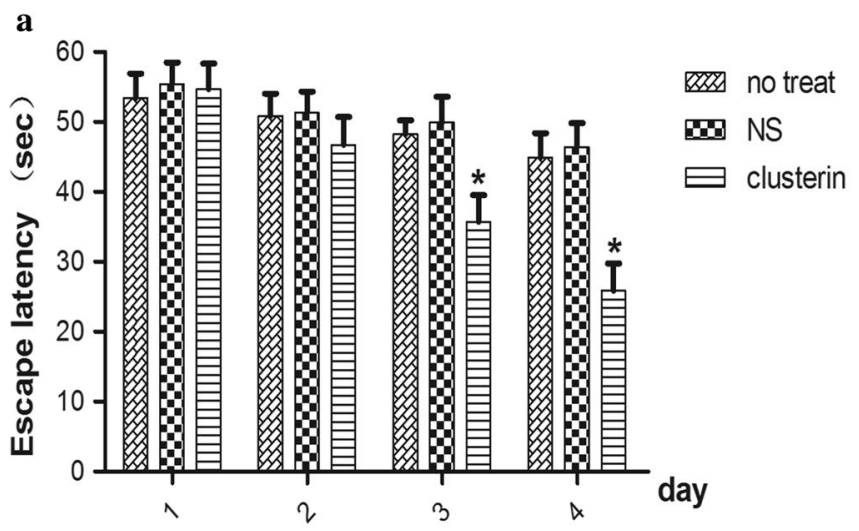

b
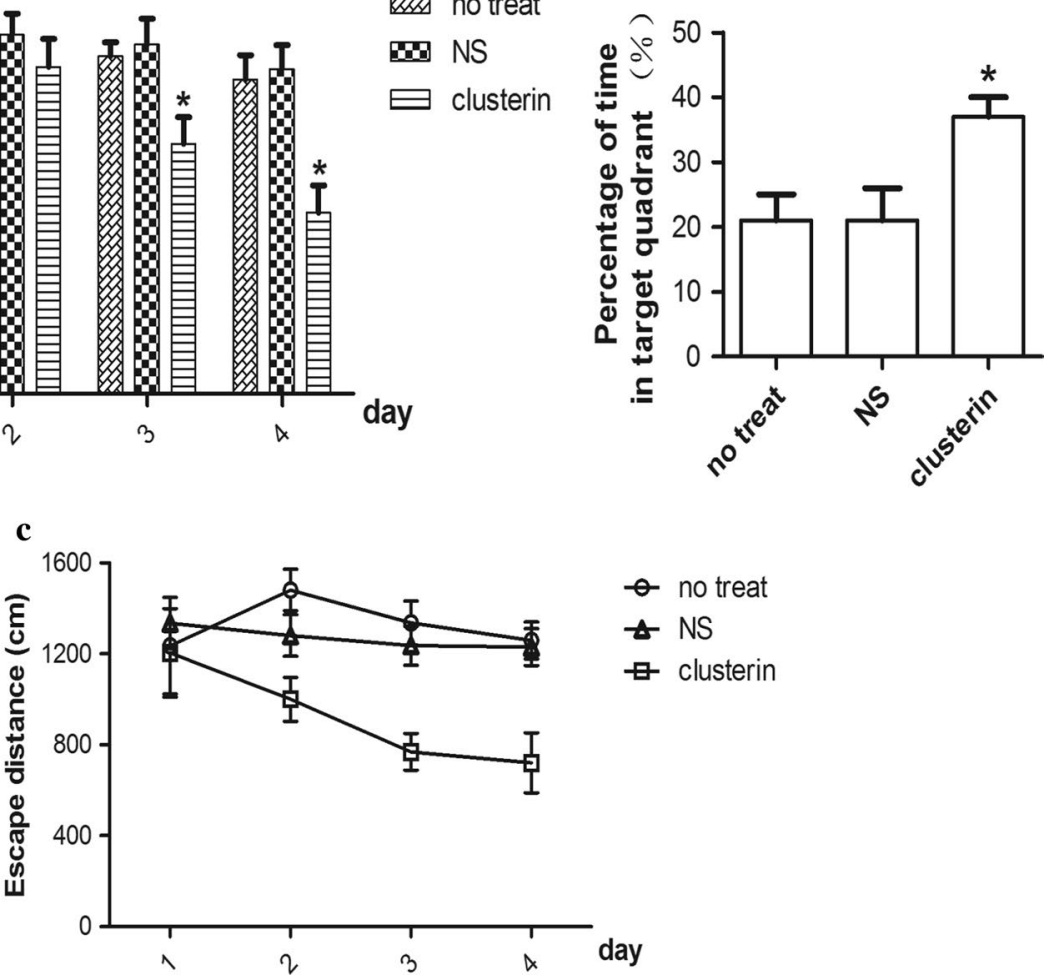

Fig. 1 Tg6799 mice showed behavioral improvement after intraventricular (icv) infusion of clusterin peptide D-[113-122]. Tg6799 mice received nothing (non-treat), saline (NS) or clusterin peptide D-[113-122] via icv infusion for 2 weeks as indicated. Acquisition trial was performed four times a day for 4 consecutive days. Swimming time (a) and distance (c) to arrive at the platform was recorded. Non-treat and NS mice showed no improvement in swimming distance in comparison to clusterin treat group, and clusterin treat group exhibited less time-to-platform. On the following day a probe test was performed and clusterin treat group showed more time spent in the goal quadrant (b) as opposed to non-treat and NS mice. Data is presented as mean \pm S.E.M. 8 months of age, $n=10$ per group. ${ }^{*} p<0.05$, one-way ANOVA followed by Turkey post hoc test 

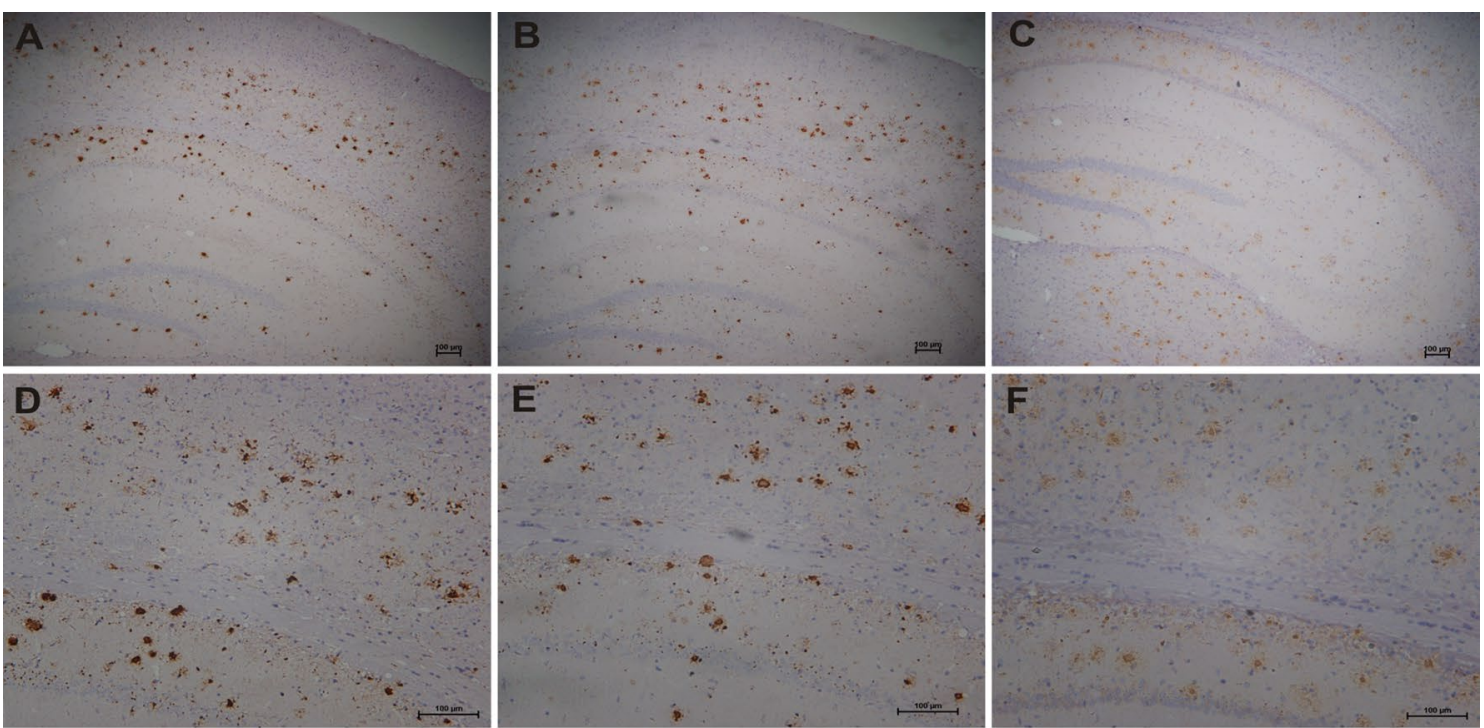

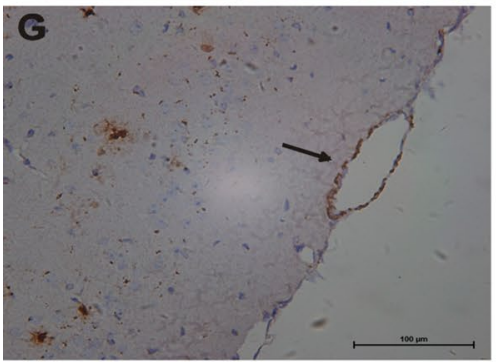

No Treat

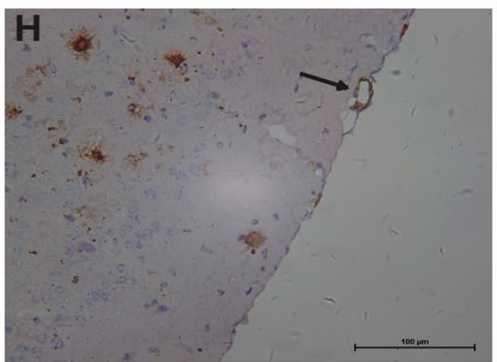

NS

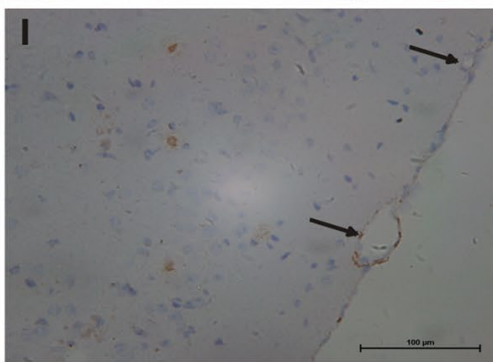

Clusterin
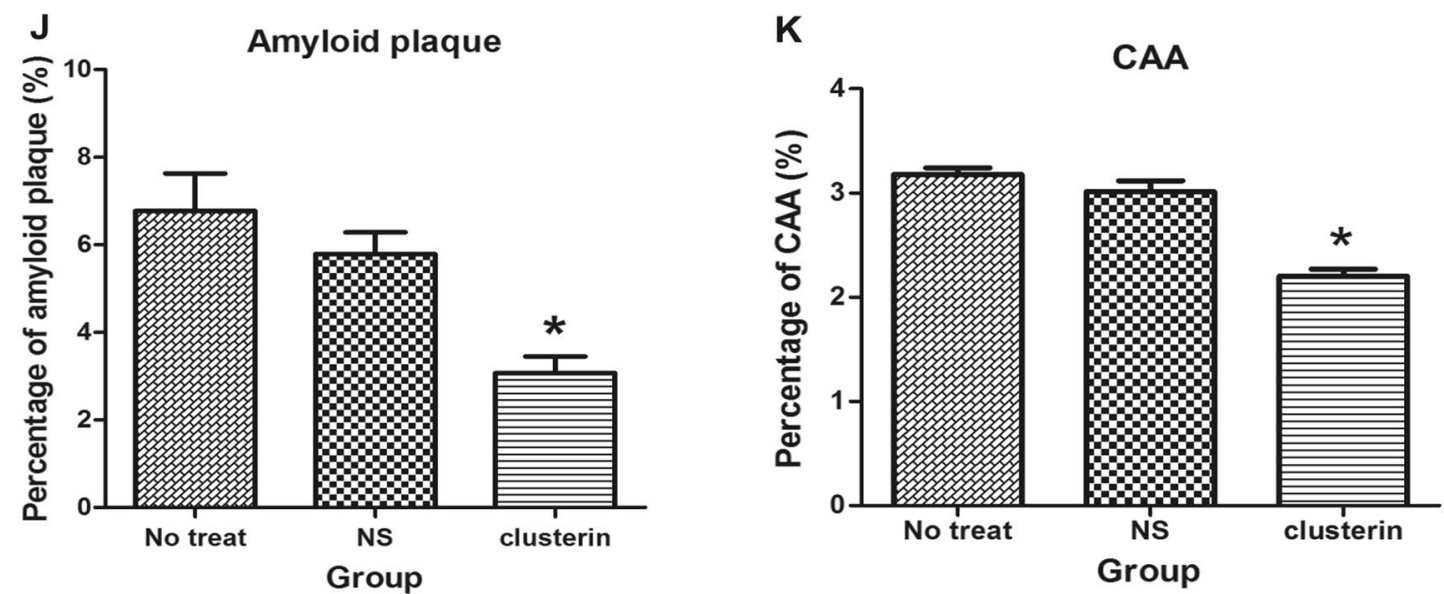

Fig. 2 Decreased amyloid plaque and CAA following 2 weeks intraventricular (icv) treatment of clusterin peptide D-[113-122] in comparison to saline (NS) or nothing (non-treat). Images show amyloid plaque burden in hippocampus of Tg6799 mouse after icv-treatment of nothing (A, D), saline (NS, B, E) and clusterin peptide D-[113-122] (C, F) as well as the CAA burden in cortical region of Tg6799 mouse after icv-treatment of nothing $(\mathbf{G})$, saline (NS, H) and clusterin peptide D-[113-122] (I). Quantitative analysis of the percentage hippocampal area (J) occupied by amyloid plaque (Aß42 immunohistochemistry study) and percentage cortical area (K) occupied by CAA (Aß40 immunohistochemistry study) demonstrated a decrease after icv infusion of clusterin in Tg6799 mouse. Analysis involved 10 serial sections per mouse for cortex and 5 serial sections for hippocampus. 8 months of age, $n=5$ per group. Data are presented as mean \pm S.E.M. Scale bar $=100 u m$. ${ }^{*} p<0.05$; one-way ANOVA followed by Turkey post hoc test 
amyloid deposition, we used ELISA kit to measure the level of soluble $A \beta 42$ and $A \beta 40$ after clusterin peptide $D$-[113-122] treatment. Soluble A $\beta 42$ were found different among three groups $(\mathrm{F}(2,25)=7.76, \mathrm{p}=0.002)$ and the following Turkey test for comparison between two groups showed that soluble $A \beta 42$ decreased in clusterin group than non-treat group $(\mathrm{p}=0.028)$ and saline group $(\mathrm{p}=0.002)$ (Fig. 3a). Soluble A $\beta 40$ were also different among three groups $(F(2,25)=9.85, \mathrm{p}=0.001)$ and in the post Turkey test soluble $A \beta 40$ were found decreased in clusterin group than non-treat group $(\mathrm{p}=0.020)$ and saline group $(\mathrm{p}=0.001)$ (Fig. $3 \mathrm{~b})$. The results showed that both soluble $A \beta 42$ and $A \beta 40$ decreased after clusterin peptide treatment.

\section{Clusterin peptide D-[113-122] increased LRP-2 level in Tg6799 transgenic mouse}

Clusterin is also implicated in affecting $A \beta$ clearance from brain and LRP-2 is the major receptor medicating the up-take of clusterin- $\mathrm{A} \beta$ complex $[18,25]$ so we further examined the expression of LRP-2 protein. We measured the level of LRP-2 protein after intraventricular infusion of clusterin peptide D-[113-122]. Using western-blot, we found that the expression of LRP-2 protein was found significantly different among three groups $(\mathrm{F}(2,25)=41.90, \mathrm{p}<0.001)$, which increased in clusterin treating group when comparing to non-treat $(\mathrm{p}<0.001)$ and saline group $(\mathrm{p}<0.001)$ (Fig. $3 \mathrm{c}, \mathrm{d})$ in the post Turkey test, suggesting that LRP-2 protein was involved in the reduction of amyloid deposition after clusterin peptide treatment in $\mathrm{AD}$ transgenic mice.

\section{Discussion}

In the present study, we investigated whether intraventricular injection of clusterin peptide D-[113-122] would affect $\mathrm{AD}$ and CAA pathology. Using Tg6799 transgenic mouse we found that intraventricular infusion clusterin peptide D-[113-122] for 2 weeks was able to ameliorate memory dysfunction of Tg6799 transgenic mouse, reduce amyloid plaque (mainly $A \beta 42$ ) in hippocampus and CAA (mainly A $\beta 40$ ) in cortical region of temporal lobe. In addition clusterin peptide decreased soluble $A \beta$ level in the transgenic mouse. We further demonstrated that clusterin peptide treatment increased the expression of LRP-2.

Accumulating evidence has revealed that decreased clearance of $\mathrm{A} \beta$ plays a key role in $\mathrm{AD}$ pathogenesis, which suggests that promoting $A \beta$ clearance could

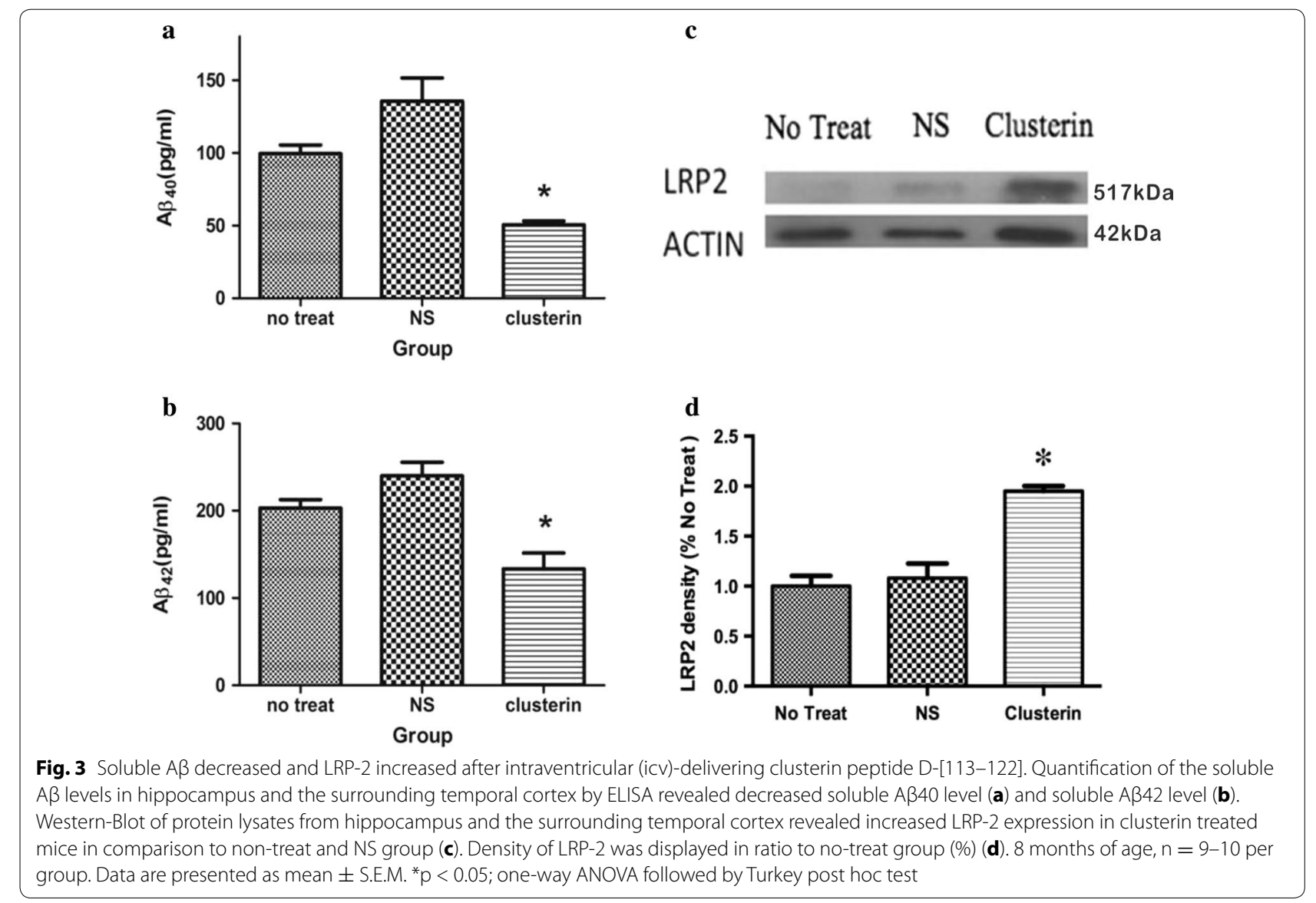

c 
provide new therapeutic targets for $\mathrm{AD}$ treatment [26]. Recent years, many clinical trial targeting on anti-A $\beta$ immunotherapies have failed in AD patients for its lack of efficiency or safety issues [27, 28], so new alternative therapeutic strategies are urgently needed. Clusterin, as a molecular chaperone, has been found to associate with $\mathrm{AD}$, however it was still not fully understood how clusterin affect $\mathrm{AD}$ pathology. Plasma clusterin level was elevated early in AD patients and associated with severity of AD [29-31]. The role of plasma clusterin elevation remained controversial. Thambisetty et al. [32] found that a higher baseline plasma clusterin level was associated with slow brain atrophy rate, suggesting that elevated plasma clusterin was probably protective for neurodegeneration. Further studies have demonstrated that clusterin is involved in the toxicity, accumulation and clearance of $\mathrm{A} \beta$ in the brain $[18,33,34]$. Clusterin was also found to have high immunoreactivity in the arterioles and capillaries of $\mathrm{AD}$ and $\mathrm{CAA}$ patients, indicating clusterin is more likely to co-locate with $A \beta 40$ rather than $A \beta 42$, so that clusterin might mediate the elimination of $A \beta 40$ through perivascular drainage pathway and be involved in CAA pathology [35]. In our study we found that intraventricular infusion clusterin peptide D-[113-122] was able to ameliorate memory dysfunction of Tg6799 transgenic mouse, reduce amyloid plaque (mainly $A \beta 42$ ) in hippocampus and CAA (mainly A $\beta 40$ ) in cortical region of temporal lobe. These results supported the protective role of clusterin and suggested that intraventricular infusion synthetic clusterin peptide might be a potential therapeutic method for modifying AD and CAA progress. And a recent research found a marked increase of CAA in the cerebrovasculature of APP-PS1 mice on a clusterin -/ - background [36], which suggested that the perivascular drainage of $A \beta$ was impaired in absence of clusterin. So clusterin may promote clearance of $A \beta$ in the perivascular drainage route by preventing the deposition of $A \beta$ on the cerebral vessels. However, knockdown clusterin protected against $A \beta$-induced apoptosis [37] and resulted in fewer fibrillar amyloid depositions [36, 38], indicating a harmful function of clusterin in amyloid deposition. Therefore, the effect of clusterin on $A \beta$ aggregation and clearance is very complex and difficult to predict. These contradictory results demand further studies to reveal the pathological and physiological roles of clusterin in $\mathrm{AD}$ pathogenesis.

As we know, clusterin is one of extracellular chaperons that can bind targeted protein to prevent its aggregation $[8,15]$. In vitro study, clusterin was found to sequestrate $A \beta 40$ or $A \beta 42$ oligomer to prevent its aggregation [39, $40]$, suggesting the neuroprotective effects of clusterin under physiological conditions. So if the therapeutic effect of clusterin was mediated by sequestrating $A \beta 40$ or A $\beta 42$ aggregates in Tg6799 transgenic mouse, we would expect increased soluble $A \beta 42$ and $A \beta 40$ after clusterin peptide treatment. However, this was not the case in our study which showed that soluble $A \beta 42$ and $A \beta 40$ were actually decreased in clusterin group, suggesting clusterin peptide might reduce the accumulation of $A \beta 42$ and $A \beta 40$ through other mechanism than its chaperone effect on aggregates of $A \beta$. Further studies are required to explore the effect of clusterin peptide on the biological behavior of brain amyloid beta as well as the mechanism involved in this process.

LRP family proteins play an important role in clearing $A \beta 42$ and $A \beta 40$ [41-43]. Drug such as simvastatin was shown to upregulate LRP to increase the $A \beta$ clearance [41]. LRP-2/meglin, as a member of the LRP family protein, has been demonstrated to mediate the transport and cellular uptake of clusterin and $A \beta$-clusterin complex at the cerebrovascular endothelium and e choroid plexus epithelium [17]. Incubation of clusterin with A $\beta 40$ could increase the LRP- 2 mediated A $\beta 40$ clearance in vitro study $[16,34]$. In our present study, clusterin peptide treatment increased the expression of LRP-2, suggesting that the therapeutic effect of clusterin might be mediated through LRP-2 pathway. So it was possible that clusterin peptide increased the $A \beta 42$ and $A \beta 40$ clearance, decreased soluble $A \beta 42$ and $A \beta 40$ level, reduced the accumulation of $A \beta 42$ and $A \beta 40$ in plaque and CAA, and finally improved the memory impairment in Tg6799 transgenic mouse. However based on current data, it was not certain whether the elevation of LRP-2 expression was a direct change after clusterin peptide treatment or "by stander" effect. As we known, clusterin exhibits various function from chaperon, immune modulation and apoptosis [44]. For instance, clusterin could bind membrane attack complex (C5b-9) to modulate complement system [45], another important system involved in AD pathogenesis [46]. LRP had complement repeat-containing domains and was found to bind complement related protein $[47,48]$. So it was also possible that clusterin peptide D-[113-122] induced complement activation first and then modulated LRP-2 expression afterwards.

In our present study, intraventricular injection was shown effective in improving memory dysfunction in $\mathrm{AD}$ animal model, however, this administration method is not applicable to patients. Moreover the effects of manipulating clusterin in $\mathrm{AD}$ transgenic mouse models or in vitro studies are difficult to predict $[40,49]$. So before making the basic neuroscience finding into clinical effective therapies in patients, we need a better understanding of the detailed mechanisms of clusterin involved in the pathogenesis of AD. 


\section{Conclusion}

So far, there are no effective treatments to modify the progress of $\mathrm{AD}$. Amyloid clearing therapies were demonstrated as an effective way to eliminate amyloid deposition in animal model [50-52]. Although clinical trials of these therapies were failed for different reasons $[27,28$, 53], it remained a promising approach for AD modifying therapy. We found that intraventricular administration of clusterin peptide D-[113-122] was able to reduce amyloid accumulation and hence improve memory impairment in Tg6799 transgenic mouse through a mechanism involving LRP-2 mediated clearance system. These findings offer another interesting therapeutic approach for modulating AD progress. However, further studies are needed to reveal the exact mechanism how clusterin peptide D-[113-122] exert its therapeutic function and what role of LRP-2 plays in this treatment.

\section{Abbreviations}

A $\beta$ : amyloid $\beta$; CAA: cerebral amyloid angiopathy; AD: Alzheimer's disease; LRP-2: Iow density lipoprotein receptor-2; icv: intraventricular; HDL: high-density lipoprotein; APP: amyloid precursor protein; PS1: presenilins 1; FAD: familial Alzheimer's disease; IACUC: Institutional Animal Care and Use Committee; PBS: phosphate buffered saline; ELISA: enzyme-linked immunosorbent assay.

\section{Authors' contributions}

QXM drafted the manuscript. WC and CXK participated in the design of the study and analysis of the results. LG participated in the analysis of the data and revised the manuscript. MJF designed the experiment, participated in data analysis and revised the manuscript. All authors read and approved the final manuscript.

\section{Acknowledgements}

Not applicable.

\section{Competing interests}

The authors declare that they have no competing interests.

\section{Availability of data and materials}

All data generated or analysed during this study are available from the corresponding author on reasonable request.

\section{Consent for publication}

Not applicable.

\section{Ethics approval and consent to participate}

All experiments with mice were performed according to the National Institutes of Health Guide for the Care and Use of Laboratory Animals with the approval (Permit Number: SYXK-2011-0113) of the Scientific Investigation Board of Shanghai Jiao Tong University School of Medicine, Shanghai, China.

\section{Funding}

This study was supported by grant from National Nature Science for Youth (No. 81200979) and National Natural Science Foundation of China (No. 81571103).

\section{Publisher's Note}

Springer Nature remains neutral with regard to jurisdictional claims in published maps and institutional affiliations.
Received: 9 March 2017 Accepted: 18 January 2018

Published online: 25 January 2018

\section{References}

1. Musiek ES, Holtzman DM. Three dimensions of the amyloid hypothesis: time, space and 'wingmen'. Nat Neurosci. 2015;18(6):800-6.

2. ladecola C. Neurovascular regulation in the normal brain and in Alzheimer's disease. Nat Rev Neurosci. 2004;5(5):347-60.

3. Ruitenberg A, den Heijer T, Bakker SL, van Swieten JC, Koudstaal PJ, Hofman A, Breteler MM. Cerebral hypoperfusion and clinical onset of dementia: the Rotterdam Study. Ann Neurol. 2005;57(6):789-94.

4. Zlokovic BV. Neurovascular mechanisms of Alzheimer's neurodegeneration. Trends Neurosci. 2005;28(4):202-8.

5. Zlokovic BV. New therapeutic targets in the neurovascular pathway in Alzheimer's disease. Neurotherapeutics. 2008;5(3):409-14.

6. Deane R, Bell RD, Sagare A, Zlokovic BV. Clearance of amyloid-beta peptide across the blood-brain barrier: implication for therapies in Alzheimer's disease. CNS Neurol Disord Drug Targets. 2009;8(1):16-30.

7. Blaschuk O, Burdzy K, Fritz IB. Purification and characterization of a cellaggregating factor (clusterin), the major glycoprotein in ram rete testis fluid. J Biol Chem. 1983;258(12):7714-20.

8. Calero M, Rostagno A, Frangione B, Ghiso J. Clusterin and Alzheimer's disease. Sub-cellular Biochem. 2005;38:273-98.

9. Harold D, Abraham R, Hollingworth P, Sims R, Gerrish A, Hamshere ML, Pahwa JS, Moskvina V, Dowzell K, Williams A, et al. Genome-wide association study identifies variants at CLU and PICALM associated with Alzheimer's disease. Nat Genet. 2009;41(10):1088-93.

10. Lambert JC, Heath S, Even G, Campion D, Sleegers K, Hiltunen M, Combarros O, Zelenika D, Bullido MJ, Tavernier B, et al. Genome-wide association study identifies variants at CLU and CR1 associated with Alzheimer's disease. Nat Genet. 2009:41(10):1094-9.

11. Carrasquillo MM, Belbin O, Hunter TA, Ma L, Bisceglio GD, Zou F, Crook JE, Pankratz VS, Dickson DW, Graff-Radford NR, et al. Replication of CLU, CR1, and PICALM associations with alzheimer disease. Arch Neurol. 2010:67(8):961-4.

12. Jun G, Naj AC, Beecham GW, Wang LS, Buros J, Gallins PJ, Buxbaum JD, Ertekin-Taner N, Fallin MD, Friedland R, et al. Meta-analysis confirms CR1 CLU, and PICALM as alzheimer disease risk loci and reveals interactions with APOE genotypes. Arch Neurol. 2010;67(12):1473-84.

13. Lee JH, Cheng R, Barral S, Reitz C, Medrano M, Lantigua R, JimenezVelazquez IZ, Rogaeva E, St George-Hyslop PH, Mayeux R. Identification of novel loci for Alzheimer disease and replication of CLU, PICALM, and BIN1 in Caribbean Hispanic individuals. Arch Neurol. 2011;68(3):320-8.

14. Ma JF, Liu LH, Zhang Y, Wang Y, Deng YL, Huang Y, Wang G, Xu W, Cui PJ, Fei QZ, et al. Association study of clusterin polymorphism rs11136000 with late onset Alzheimer's disease in Chinese Han population. Am J Alzheimer's Dis Other Dement. 2011;26(8):627-30.

15. DeMattos RB, Brendza RP, Heuser JE, Kierson M, Cirrito JR, Fryer J, Sullivan PM, Fagan AM, Han X, Holtzman DM. Purification and characterization of astrocyte-secreted apolipoprotein $\mathrm{E}$ and J-containing lipoproteins from wild-type and human apoE transgenic mice. Neurochem Int. 2001;39(5-6):415-25.

16. Hammad SM, Ranganathan S, Loukinova E, Twal WO, Argraves WS. Interaction of apolipoprotein J-amyloid beta-peptide complex with low density lipoprotein receptor-related protein-2/megalin. A mechanism to prevent pathological accumulation of amyloid beta-peptide. J Biol Chem. 1997:272(30):18644-9.

17. Zlokovic BV, Martel CL, Matsubara E, McComb JG, Zheng G, McCluskey RT, Frangione B, Ghiso J. Glycoprotein 330/megalin: probable role in receptor-mediated transport of apolipoprotein $\mathrm{J}$ alone and in a complex with Alzheimer disease amyloid beta at the blood-brain and bloodcerebrospinal fluid barriers. Proc Natl Acad Sci USA. 1996;93(9):4229-34.

18. DeMattos RB, Cirrito JR, Parsadanian M, May PC, O'Dell MA, Taylor JW, Harmony JA, Aronow BJ, Bales KR, Paul SM, et al. ApoE and clusterin cooperatively suppress $A \beta$ levels and deposition: evidence that $A p o E$ regulates extracellular A $\beta$ metabolism in vivo. Neuron. 2004;41(2):193-202. 
19. Zlokovic BV. Cerebrovascular transport of Alzheimer's amyloid beta and apolipoproteins J and E: possible anti-amyloidogenic role of the bloodbrain barrier. Life Sci. 1996:59(18):1483-97.

20. Navab M, Anantharamaiah GM, Reddy ST, Van Lenten BJ, Wagner AC, Hama S, Hough G, Bachini E, Garber DW, Mishra VK, et al. An oral apoJ peptide renders $\mathrm{HDL}$ antiinflammatory in mice and monkeys and dramatically reduces atherosclerosis in apolipoprotein E-null mice. Arterioscler Thromb Vasc Biol. 2005;25(9):1932-7.

21. Thakker DR, Weatherspoon MR, Harrison J, Keene TE, Lane DS, Kaemmerer WF, Stewart GR, Shafer LL. Intracerebroventricular amyloidbeta antibodies reduce cerebral amyloid angiopathy and associated micro-hemorrhages in aged Tg2576 mice. Proc Natl Acad Sci USA. 2009;106(11):4501-6.

22. Oakley H, Cole SL, Logan S, Maus E, Shao P, Craft J, Guillozet-Bongaarts A, Ohno M, Disterhoft J, Van Eldik L, et al. Intraneuronal beta-amyloid aggregates, neurodegeneration, and neuron loss in transgenic mice with five familial Alzheimer's disease mutations: potential factors in amyloid plaque formation. J Neurosci. 2006;26(40):10129-40.

23. Morris R. Developments of a water-maze procedure for studying spatial learning in the rat. J Neurosci Methods. 1984;11(1):47-60.

24. Echeverria V, Burgess S, Gamble-George J, Zeitlin R, Lin X, Cao C, Arendash GW. Sorafenib inhibits nuclear factor kappa B, decreases inducible nitric oxide synthase and cyclooxygenase-2 expression, and restores working memory in APPswe mice. Neuroscience. 2009;162(4):1220-31.

25. Gliemann J. Receptors of the low density lipoprotein (LDL) receptor family in man. Multiple functions of the large family members via interaction with complex ligands. Biol Chem. 1998:379(8-9):951-64.

26. Saito S, Ihara M. New therapeutic approaches for Alzheimer's disease and cerebral amyloid angiopathy. Front Aging Neurosci. 2014;6:290.

27. Mangialasche F, Solomon A, Winblad B, Mecocci P, Kivipelto M. Alzheimer's disease: clinical trials and drug development. Lancet Neurol. 2010;9(7):702-16.

28. Vellas B, Carrillo MC, Sampaio C, Brashear HR, Siemers E, Hampel H, Schneider LS, Weiner M, Doody R, Khachaturian Z, et al. Designing drug trials for Alzheimer's disease: what we have learned from the release of the phase III antibody trials: a report from the EU/US/CTAD Task Force. Alzheimer's Dement J Alzheimer's Assoc. 2013;9(4):438-44.

29. Schrijvers EM, Koudstaal PJ, Hofman A, Breteler MM. Plasma clusterin and the risk of Alzheimer disease. JAMA. 2011;305(13):1322-6

30. Desikan RS, Thompson WK, Holland D, Hess CP, Brewer JB, Zetterberg $\mathrm{H}$, Blennow K, Andreassen OA, McEvoy LK, Hyman BT, et al. The role of clusterin in amyloid-beta-associated neurodegeneration. JAMA Neurol. 2014;71(2):180-7.

31. Thambisetty M, Simmons A, Velayudhan L, Hye A, Campbell J, Zhang Y, Wahlund LO, Westman E, Kinsey A, Guntert A, et al. Association of plasma clusterin concentration with severity, pathology, and progression in Alzheimer disease. Arch Gen Psychiatry. 2010;67(7):739-48.

32. Thambisetty M, An Y, Kinsey A, Koka D, Saleem M, Guntert A, Kraut M, Ferrucci L, Davatzikos C, Lovestone S, et al. Plasma clusterin concentration is associated with longitudinal brain atrophy in mild cognitive impairment. Neurolmage. 2012;59(1):212-7.

33. Oda T, Wals P, Osterburg HH, Johnson SA, Pasinetti GM, Morgan TE, Rozovsky I, Stine WB, Snyder SW, Holzman TF, et al. Clusterin (apoJ) alters the aggregation of amyloid beta-peptide $\left(A \beta_{1-42}\right)$ and forms slowly sedimenting $A \beta$ complexes that cause oxidative stress. Exp Neurol. 1995;136(1):22-31.

34. Bell RD, Sagare AP, Friedman AE, Bedi GS, Holtzman DM, Deane R, Zlokovic BV. Transport pathways for clearance of human Alzheimer's amyloid beta-peptide and apolipoproteins $\mathrm{E}$ and $\mathrm{J}$ in the mouse central nervous system. J Cereb Blood Flow Metab. 2007;27(5):909-18.

35. Craggs L, Taylor J, Slade JY, Chen A, Hagel C, Kuhlenbaeumer G, Borjesson-Hanson A, Viitanen M, Kalimo H, Deramecourt V, et al. Clusterin/Apolipoprotein $\mathrm{J}$ immunoreactivity is associated with white matter damage in cerebral small vessel diseases. Neuropathol Appl Neurobiol. 2016;42(2):194-209.
36. Wojtas AM, Kang SS, Olley BM, Gatherer M, Shinohara M, Lozano PA, Liu CC, Kurti A, Baker KE, Dickson DW et al. Loss of clusterin shifts amyloid deposition to the cerebrovasculature via disruption of perivascular drainage pathways. In: Proceedings of the National Academy of Sciences of the United States of America. 2017.

37. Killick R, Ribe EM, Al-Shawi R, Malik B, Hooper C, Fernandes C, Dobson R, Nolan PM, Lourdusamy A, Furney $S$, et al. Clusterin regulates $\beta$-amyloid toxicity via Dickkopf-1-driven induction of the wnt-PCP-JNK pathway. Mol Psychiatry. 2014;19(1):88-98.

38. DeMattos RB, O'Dell MA, Parsadanian M, Taylor JW, Harmony JA, Bales KR, Paul SM, Aronow BJ, Holtzman DM. Clusterin promotes amyloid plaque formation and is critical for neuritic toxicity in a mouse model of Alzheimer's disease. Proc Natl Acad Sci USA. 2002;99(16):10843-8.

39. Narayan P, Orte A, Clarke RW, Bolognesi B, Hook S, Ganzinger KA, Meehan S, Wilson MR, Dobson CM, Klenerman D. The extracellular chaperone clusterin sequesters oligomeric forms of the amyloid-beta(1-40) peptide. Nat Struct Mol Biol. 2011;19(1):79-83.

40. Yerbury JJ, Poon S, Meehan S, Thompson B, Kumita JR, Dobson CM, Wilson MR. The extracellular chaperone clusterin influences amyloid formation and toxicity by interacting with prefibrillar structures. FASEB J. 2007;21(10):2312-22.

41. Deane R, Wu Z, Zlokovic BV. RAGE (yin) versus LRP (yang) balance regulates alzheimer amyloid beta-peptide clearance through transport across the blood-brain barrier. Stroke J Cereb Circ. 2004;35(11 Suppl 1):2628-31.

42. Sagare A, Deane R, Bell RD, Johnson B, Hamm K, Pendu R, Marky A, Lenting PJ, Wu Z, Zarcone T, et al. Clearance of amyloid-beta by circulating lipoprotein receptors. Nat Med. 2007;13(9):1029-31.

43. Kanekiyo T, Liu CC, Shinohara M, Li J, Bu G. LRP1 in brain vascular smooth muscle cells mediates local clearance of Alzheimer's amyloid-beta. J Neurosci. 2012;32(46):16458-65.

44. Nuutinen T, Suuronen T, Kauppinen A, Salminen A. Clusterin: a forgotten player in Alzheimer's disease. Brain Res Rev. 2009;61(2):89-104.

45. Choi NH, Mazda T, Tomita M. A serum protein SP40,40 modulates the formation of membrane attack complex of complement on erythrocytes. Mol Immunol. 1989;26(9):835-40.

46. Shen Y, Yang L, Li R. What does complement do in Alzheimer's disease? Old molecules with new insights. Transl Neurodegener. 2013;2(1):21.

47. Dolmer K, Gettins PG. Three complement-like repeats compose the complete a2-macroglobulin binding site in the second ligand binding cluster of the low density lipoprotein receptor-related protein. J Biol Chem. 2006;281(45):34189-96

48. Westein E, Denis CV, Bouma BN, Lenting PJ. The alpha-chains of C4bbinding protein mediate complex formation with low density lipoprotein receptor-related protein. J Biol Chem. 2002;277(4):2511-6.

49. Beeg M, Stravalaci M, Romeo M, Carra AD, Cagnotto A, Rossi A, Diomede L, Salmona M, Gobbi M. Clusterin binds to AB1-42 oligomers with high affinity and interferes with peptide aggregation by inhibiting primary and secondary nucleation. J Biol Chem. 2016;291(13):6958-66.

50. Bard F, Cannon C, Barbour R, Burke RL, Games D, Grajeda H, Guido T, Hu K, Huang J, Johnson-Wood K, et al. Peripherally administered antibodies against amyloid beta-peptide enter the central nervous system and reduce pathology in a mouse model of Alzheimer disease. Nat Med. 2000;6(8):916-9.

51. Rinne JO, Brooks DJ, Rossor MN, Fox NC, Bullock R, Klunk WE, Mathis CA, Blennow K, Barakos J, Okello AA, et al. 11C-PiB PET assessment of change in fibrillar amyloid-beta load in patients with Alzheimer's disease treated with bapineuzumab: a phase 2, double-blind, placebo-controlled, ascending-dose study. Lancet Neurol. 2010;9(4):363-72.

52. Blennow K, Zetterberg H, Rinne JO, Salloway S, Wei J, Black R, Grundman M, Liu E. Effect of immunotherapy with bapineuzumab on cerebrospinal fluid biomarker levels in patients with mild to moderate Alzheimer disease. Arch Neurol. 2012;69(8):1002-10.

53. Mullane K, Williams M. Animal models of asthma: reprise or reboot? Biochem Pharmacol. 2014:87(1):131-9. 